\title{
Problem Solving through Teamwork Using Puzzle Media for 10 years old Children in Dukuhwaluh Village
}

\author{
Pemecahan Masalah Melalui Kerja Sama Tim \\ Menggunakan Media Puzzle Anak Usia 10 Tahun di Desa Dukuhwaluh
}

\begin{abstract}
Gisella Arnis Grafiyana ${ }^{1}$, Intan Nur Rahmawati ${ }^{2}$, Lutfi Septiana Widyastuti ${ }^{3}$, Syavira Berliana Syaskia Dewi $^{4}$, Fanisa Dwi Oktaviana ${ }^{5}$, Aprilia Dwi Ayomi ${ }^{6}$, Gina Safitri Rachmatillah ${ }^{7}$, Antin Rohmawati ${ }^{8}$

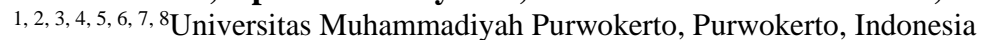

\begin{tabular}{l} 
ARTICLE INFO \\
\hline Article history: \\
DOI: \\
$\underline{\text { 10.30595/pssh.v2i.95 }}$
\end{tabular}

Submitted: July 16, 2021

Accepted: Sept 16, 2021

Published: Sept 24, 2021

\section{Keywords:}

Child Development,

Experiment, Problem

Solving, Puzzle, Teamwork

\begin{abstract}
Problem solving is a process that has been implemented in order to obtain a solution to a problem that is carried out in stages. Teamwork is the ability of individuals to work together with others and aims for members to be able to participate in the team and understand their duties. This study aims to determine the ability to solve problems and teamwork (teamwork) in children aged 10 years using puzzles. This research is an experimental study with a quasi-experimental design: non-equivalent control group design. The participants in this study were 8 children aged 10 years consisting of 5 boys and 3 girls. The data collection in this study was the acquisition of time in the preparation of puzzles. The data that has been obtained is then analyzed using the t-test (t-test). The results of this study indicate that the experimental group has faster problem solving than the control group because of the learning outcomes of teamwork.
\end{abstract}

This work is licensed under a Creative Commons Attribution 4.0 International License.

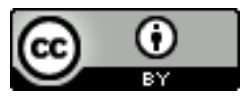

Corresponding Author:

Gisella Arnis Grafiyana

Universitas Muhammadiyah Purwokerto, Indonesia

Email: gisella.arnis@ump.ac.id

\section{INTRODUCTION}

Children are individuals who have thoughts, feelings, attitudes and interests that are different from adults and have all the limitations (Sobur, 1988). Children are small creatures who need protection, love and a proper place for their development. In addition, children are part of the family and families can provide opportunities for children to learn behavior for development in everyday life during childhood (Damayanti, 1992). Based on the stage of cognitive development (Piaget, 1950) the subject is in the concrete operational stage aged 7-11 years. The age of the subject who took part in the puzzle experiment was 10 years, which means that the subject was in the concrete operational stage.

School learning tends to be very academic and not related to the environment in which children live, so that child participants do not apply what they have learned in school and solve life problems that are being faced in everyday life (Wardaya, 2009). Learning is the process of the relationship between students and educators towards learning resources in the child's learning environment (Damayanti, 1992).

During the covid-19 pandemic, online learning is inevitable so educators must quickly adapt to shift their learning media from offline to online. Online learning is a form of learning that is connected to the internet network. An online learning system that uses media such as Google, YouTube, and various types of media. Online learning is an open and distributed learning system using educational aids such as the internet and media that use networks for the learning process (Horvitz, 2007). Hamalik (1986) in his book describes the media of education as tools, methods, and techniques used to improve the transfer of information and communication between teachers and 
students during the process of education and learning in school.

Finally, educators are required to develop interesting learning media online while still adjusting the age and development period of children so that the goal of educating and increasing children's creativity is still achieved despite the reduced face-to-face aspects in the learning information transfer process in the classroom. For this reason, in this study will be studied in groups and individuals in improving the ability of children to solve problems through puzzle work.

\section{THEORITICAL FRAMEWORK}

Stage of Intellectual Development

Cognitive development is the growth of logical thinking from infancy to adulthood. Children's intellectual development is distinguished in 4 stages, namely: sensory-motor stage, pre-operational stage, concrete operational stage, and formal operational stage (Jarvis, 2017). Jean Piaget believed that everyone goes through all four stages, even though each stage is passed in a different age. Each stage is entered when our brain is mature enough to allow for a new kind of logic or surgery (Jarvis, 2017). All humans go through each of these levels, at different speeds.

\section{Sensorimotor stage}

The sensorimotor stage starts from birth to age 2, babies begin to learn about themselves and their world through senses that develop through motor activity. Cognitive activity centered on sensory or sensory devices and motion or motor, meaning that in this stage the child is only able to do environmental recognition through sensory and movement tools. This stage is the basis for further cognitive development, motor sensory activity is formed through the process of adjusting physical structures because of interaction with the environment (Surya, 2003).

2. Pre-Operational Stage

The pre-operational stage of the child shows cognitive activity in dealing with various things outside of him. His thinking activities do not yet have an organized system. Children can understand reality in the environment by using signs and symbols. The way children think at this level is unsystematic, inconsistent, and illogical (Surya, 2003).

3. Concrete Operational Stage

The child's concrete operational stage is mature enough to use logical thinking or surgery, but only for the physical object that exists today. At this stage, the child loses his tendency toward animism and artificialism. His egocentricity is diminished and his ability in conversion tasks for the better. However, without physical objects in front of them, children will have great difficulty in completing logic tasks (Jarvis, 2017).

4. Formal Operational Stage

At the age of 12 years and above, a new period of operation arises that uses concrete operations to form more complex operations (Jarvis, 2017). Progress in children during this period is that he does not need to think with the help of concrete objects or events, he can think abstractly. Children are already able to understand the form of argument and are not confused by the side of the argument and therefore called formal operations.

\section{Problem Solving}

Problem solving or problem solving is a knowledge that is used to solve problems procedurally or declarative memory that can apply analytical skills, inferential skills and appraisal options and procedures or produce appropriate strategies to get answers to certain problems (Heppner \& Petersen, 1982). Problem solving is finding solutions to the difficulties faced in life to reduce ambiguity and achieve goals that are sometimes incomprehensible to every individual (Reed, 2011).

Problem solving is defined as a process involved in trying to find the right sequence of alternative answers, working on a single goal or towards an ideal solution (Chaplin, 2011). Problem solving or problem solving is a process of eliminating differences or discrepancies that occur between the results obtained and the desired results (Hunsaker, 2005)(Hunsaker, 2005). Problem solving as an attempt to find a way out of a goal that is not so easy to achieve immediately (Adul, 2012).

\section{Aspect Problem Solving}

There are three aspects of problem solving, namely self-confidence in solving problems (problem solving confidence), approach or avoidance style (approach-avoidance style), and personal control (Heppner \& Petersen, 1982) which are explained as follows:

1) Self-confidence in solving problems (problem solving confidence), individual self-confidence in solving problems. Self-confidence, namely ensuring the ability and self-assessment in carrying out tasks and choosing an effective approach. This includes confidence in their ability to face an increasingly challenging environment and trust in their own decisions or opinions (Heppner \& Petersen, 1982).

2) Approach or avoidance style (approach-avoidance style) is an aspect that aims to measure the tendency to avoid or approach various activities for problem solving (Heppner \& Petersen, 1982).

3) Personal control (personal control) is an aspect that assesses an individual's belief in deciding whether or not to use a well-designed systematic plan when facing a problem (Heppner \& Petersen, 1982). 


\section{Problem Solving Factors}

There are four factors that can influence problem solving, namely motivation, beliefs and wrong attitudes, habits, and emotions (Rahmat, 2001) which are described as follows:

1. Motivation, low motivation will distract to reduce the sense of responsibility in the face of problem, while high motivation will add to the sense of responsibility in the face of a problem (Rahmat, 2001).

2. Trust and wrong attitudes, wrong assumes can mislead the problem. If one believes happiness can be obtained by material wealth, the individual will have difficulty in solving inner suffering. A reference framework that is not careful can inhibit the effectiveness of problem solving (Rahmat, 2001).

3. Habits, tendencies to maintain a certain mindset or see the problem as only one side or overconfidence and uncritical belief in authority opinions hinder efficient problem solving (Rahmat, 2001).

4. Emotions, in the face of various situations without a person consciously being emotionally involved. These emotions color the way of thinking human being, the individual cannot override emotions, individuals cannot think objectively. Emotions can be the main activity and cause people to find it difficult to think efficiently when emotions have reached such a high intensity that they become stressed, and their behavior becomes distorted (Rahmat, 2001).

There are four factors that support problem solving, namely memory ability, giving meaning to the problem, individual understanding of information relevant to the problem, the ability to recall information from long-term memory, metacognitive processes (Ormrod, 2003) described as follows:

1. Memory ability, remembering in the period required the ability to associate various information, then memory plays an important role (Ormrod, 2003).

2. Given meaning to the problem, the problem will be easier to understand if represented meaningfully. A better understanding of the problem will affect the success of problem solving (Ormrod, 2003).

3. The better the individual's understanding of the information relevant to the problem, the better the individual's understanding of the various information related to the problem, the more likely it will be for the individual to look for various problem-solving alternatives (Ormrod, 2003).

4. The ability to recall information from long-term memory, this will be related to the knowledge that a person already has. If an individual is able to recall information from long-term memory, it will certainly help that individual collaborate that information for use in problem-solving efforts (Ormrod, 2003).

5. Metacognitive process, which is the understanding of cognitive abilities and their efforts in optimizing those abilities. Individuals who understand how cognitive abilities are possessed and how to optimize them tend to have more adequate problem-solving abilities (Ormrod, 2003).

\section{Teamwork}

Teamwork is an effort to achieve organizational goals by uniting the goals that are owned by each member of the organization in order to get a harmonious synergy for the creation of good cooperation and mutual support for each other (Rahmayanty, 2013). Teamwork itself can be interpreted as the ability of individuals to work together with other members to achieve common goals to obtain team satisfaction. This is done by understanding roles and tasks, trusting and supporting each other and working together to achieve common goals (Robbins, 2002).

Teamwork is also a group of people who work together and relate to each other and trust each other, honesty, responsibility to achieve common goals, and provide ideas for solving various problems that exist within the team that aim to increase organizational effectiveness.

Aspect Teamwork

Organizational development requires team work and is divided into five aspects (Surya, 2003)(Muhammad, 2005), namely:

1) Clear goals and directions, this is because the steps taken can be in accordance with the goals of the organization going forward

2) Good leadership is needed to regulate organizational members so that they can work together to achieve organizational goals

3) Division of tasks, this division is expected to complete the task according to the deadline

4) Records of needs, to supply the needs of members of the organization to achieve its goals

A supportive organizational environment, by supporting each other regardless of their background

\section{RESEARCH METHODOLOGY}

The experimental research used in this study is a quasi-experimental design: non-equivalent control group design. The researcher used this research method because the researcher wanted to group the subjects in the control and experimental groups based on the results of the pretest that had been carried out. The participants used were 8 grade 4 elementary school students aged 10 years consisting of 5 boys and 3 girls. The measuring instrument used is the speed of the pretest and posttest puzzles of 25 pieces. Manipulation in this study is a guideline puzzle and heterogeneous grouping. Analysis of the data used in the form of t-test with SPSS 25.00 for windows. 


\section{RESULTS AND DISCUSSION}

Based on the puzzle used for the Pre-test and Post-test. The demographic data are known as table follows:

Table 1. Demographics

\begin{tabular}{ccc}
\hline Demographics & Number & Percentage \\
\hline Gender & 5 & $62,5 \%$ \\
Male & 3 & $37,5 \%$ \\
Female & & \\
Age & 8 & $100 \%$ \\
\hline
\end{tabular}

Subjects consisted of 5 children (62.5\%) male and female, while 3 girls (37.5\%). All subjects were 10 years old with a percentage of $100 \%$.

Table 2. Descriptive Analysis of Pre-test and Post-test Scores

\begin{tabular}{cccccc}
\hline & N & Min & Max & Mean & SD \\
\hline Pretest & 8 & 599 & 2253 & 1345,00 & 597,277 \\
Post test & 8 & 148 & 1027 & 588,75 & 390,183 \\
\hline
\end{tabular}

Based on the mean score of table 2, it is known that there is a decrease in the mean scores of Pre-Test and Post-Test, which was originally 1345.00 to 588.75 . The speed of the subject also increased, from 599 seconds to 148 seconds, meaning that there was an increase in the score in solving the subject's problem in solving the 25-piece puzzle before being given an experiment in the form of groups.

Table 3. Pre-test Score Per Individual

\begin{tabular}{cc}
\hline Subject & Pre-test (s) \\
\hline A & 599 \\
B & 640 \\
C & 1041 \\
D & 1217 \\
E & 1481 \\
F & 1500 \\
G & 2029 \\
H & 2253
\end{tabular}

The table 3 is a different test in the preparation of individual puzzles to determine the effectiveness of the experiments that have been carried out. The results of the pre-test became the basis for dividing the groups. This is done to prove the performance of teamwork and problem solving through the learning process of everyone. The division of the group was divided into two groups, namely the control group and the experimental group. Each group consists of 1 control group and 3 experimental groups. The control group consisted of two subjects with an average speed. While the experimental group is a heterogeneous group consisting of one subject with an average speed and one subject below the average.

Table 4. Experimental Measurement Results

\begin{tabular}{ccc}
\hline Group & Subject & Times \\
\hline Control Group & D \& E & 1 hours 45 minutes 12 seconds \\
Experiment Group 1 & A \& H & 1 hours 4 minutes 56 seconds \\
Experiment Group 2 & B \& G & 1 hours 5 minutes 26 seconds \\
Experiment Group 3 & C \& F & 1 hours 19 minutes 55 seconds \\
\hline
\end{tabular}

The results of the table above show a significant time difference when the homogeneous group (control) was given an 80-piece puzzle without a guide, while the heterogeneous group (experimental) was given an 80-piece puzzle with a guide. This means that the group given the guide has a better performance than the control group. The fastest time difference is 1 hour 4 minutes 12 seconds without an error, inversely proportional to the control group which takes longer with an additional 43 minutes longer.

Table 5. Pre-test and Post-Test Result

\begin{tabular}{ccc}
\hline Subject & Pre-test (s) & Post-test (s) \\
\hline A & 599 & 154 \\
B & 640 & 148 \\
C & 1041 & 413 \\
D & 1217 & 464 \\
E & 1481 & 467 \\
F & 1500 & 865 \\
G & 2029 & 1207 \\
H & 2253 & 992 \\
\hline
\end{tabular}

The table 5 shows significant changes in individuals with below-average puzzle work. This is evidenced by the subjects $\mathrm{F}, \mathrm{G}$ and $\mathrm{H}$ which increased sharply compared to the pre-test. The learning process and teamwork determine the problem solving of everyone in completing a task. 
Table 6. One Sample Test T-Test Results

One-Sample Test

Test Value $=0$

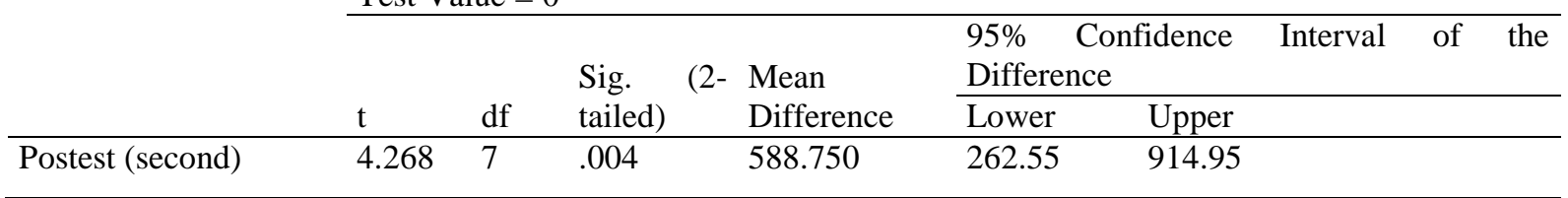

The pre-test and post-test different test using non-parametric test Ounces sample test, because the data is normally distributed. The results on table 6 showed $p<0.05$, meaning that there were differences in the results of the pre-test and post-test for everyone after being given treatment. The formation of heterogeneous groups and the provision of guidelines have been proven to be effective in improving children's problem solving.

Team formation can result in higher performance than when working individually. Teamwork shows an effort to achieve something, so that when everyone who is a member of the team has different abilities that are used as strengths. The provision of guide puzzles is the right medium in developing aspects of children's learning. The use of the right media will motivate children to learn. The use of learning media in the teaching and learning process can bring new interests, generate motivation, increase in learning activities, and can provide psychological effects on children (Malwa, 2018).

Experimental research with media intervening methods adjusted for the age of students is also conducted by (Astuti et al., 2020) using animal manipulative lotto media to improve the ability to recognize the concept of numbers for the age of kindergarten children. The result found is that when the media is applied well then, the child's ability to know the concept of numbers will increase.

\section{CONCLUSION}

Based on the results of data processing regarding problem solving and teamwork skills with puzzles in children aged 10 years in Dukuhwaluh, it was concluded that problem solving and teamwork skills through puzzles showed an increase, it can be seen from the results of the pretest and posttest. In this experimental study using a quasi-experimental design: the non-equivalent control group design is almost the same as the pre-test post-test control group design, only in this design the experimental group and control group are not chosen randomly. In this design, both the experimental and control groups are compared. Two groups (experimental and control) were given a pre-test, then given treatment, and finally given a post-test. Problem solving and teamwork skills in children aged 10 years through puzzles formed by the experimental group and the control group. The duration of time in compiling the puzzle where the time obtained during the pretest and posttest has a different time, this is evidenced that the duration of time obtained during the post test is shorter than the time obtained during the pretest there are significant results as evidenced by the results of the Test of Normality which is 0.651 . From the results of experimental tests conducted on 8 subjects consisting of the experimental group and the control group, it shows that the existence of teamwork can provide an increase in problem solving in children.

Based on the research results, the suggestions that researchers can give are expected to provide socialization in improving problem solving in children through teamwork so that children can be honed and trained in problem solving thinking processes. The weakness of this study is that there are still several variables that can affect problem solving in children. The results of this study are expected to be used as educational materials for early childhood to better understand the importance of cognitive development in early childhood and the thinking process in problem solving. Future researchers are expected to develop research on problem solving with teamwork. Other researchers can conduct research with other methods or other variables that can affect children's thinking processes. The advantage of this research is the emergence of new discoveries regarding the improvement in problem solving through teamwork with puzzles.

\section{REFERENCES}

Adul, A. (2012). Kemampuan Pemecahan Masalah Matematika Siswa Pada Pembelajaran Problem Solving Berkelompok. Jurnal Jurusan Matematika, FMIPA, Unesa.

Astuti, E. M., Novianti, R., \& Febrialismanto, F. (2020). Meningkatkan Kemampuan Mengenal Konsep Bilangan Melalui Media Animals Manipulatife Lotto Pada Anak Usia 5-6 Tahun Di Tk Alfarizky Kids Kabupaten Kampar. Jurnal Review Pendidikan Dan Pengajaran, 3(1), 97-107.

Chaplin, J. (2011). Kamus Lengkap Psikologi. Raja Grafindo Persada.

Damayanti. (1992). pengertian anak tinjauan kronologis dan psikologis.

Heppner, P., \& Petersen, C. (1982). The Development and Implications of a Personal Problem-Solving Inventory. Journal of Counseling Psychology, 26, 66-75.

Horvitz, B. S. (2007). N. Dabbagh and B. Bannan-Ritland, Online Learning: Concepts, Strategies, and Application. Educational Technology Research and Development, 55(6), 667-669. https://doi.org/10.1007/s11423-007-9071-4 Hunsaker. (2005). Community Worl and Problem Solving. McMillan.

Malwa, R. U. (2018). Dukungan Sosial Orangtua Dengan Motivasi Belajar Siswa Putra Tahfidz Al-Qur'an. Psikis: Jurnal Psikologi Islami, 3(2), 137. https://doi.org/10.19109/psikis.v3i2.1758

Proceedings homepage: https://conferenceproceedings.ump.ac.id/index.php/pssh/issue/view/7 
ISBN: 978-602-6697-94-3

Muhammad. (2005). Teori Komunikasi Antar Pribadi. Kencana Prenada Ridjaja.

Ormrod, J. (2003). Educational Psychology Developing Learners 4ed Edition. Pearson Education, Inc.

Piaget, J. (1950). The Psychology of Intelligence. Routledge.

Rahmayanty, N. (2013). Manajemen Pelayanan Prima. Graha Ilmu.

Reed. (2011). Kognisi: Teori dan Aplikasi. Salemba Humanika.

Robbins, S. P. (2002). Prinsip- Prinsip Perilaku Organisasi Edisi Kelima. Erlangga.

Sobur, A. (1988). Pembinaan Anak Dalam Keluarga. BPK Gunung Mulia.

Wardaya, D. (2009). Motivasi wirausaha siswa SMK DIY. Universitas Negeri Yogyakarta. 